\author{
Basiurkina N. \\ Doctor of Economics, Associate Professor \\ E-mail:nbas@email.ua \\ Shaleny V. \\ Assistant \\ Department of Management of Business \\ Odessa National Academy of Food Technologies \\ Kanatna str., 112, Odesa, Ukraine, 65039 \\ E-mail: shalenyy@i.ua
}

\title{
FEATURES OF RISK ASSESSMENT OF INDUSTRIAL ENTERPRISES ACTIVITIES
}

The article deals with the main theoretical aspects of risk assessment of industrial enterprises in the short-and long-term periods. The main features of short-term and long-term risks inherent to industrial enterprises have been determined. Comprehensive risk assessment methodology has been developed based on obtaining coherent assessment of the level of short-term and long-term risks. This methodology can be implemented in the form of an express assessment (simplified risk assessment) and in the form of risk matrix (advanced assessment of risks), depending on the objectives of the assessment, available resources and other constraints. The expediency of using an express assessment is, first of all, in the analysis of dynamics of the level of risk at the enterprise. By positioning the risk profile of an enterprise in a certain area of the matrix of risks, it is possible to determine the main reserves for reducing the overall level of risk and increase the effectiveness of risk management. The assessment of the risk level dynamics of activity, obtained in the form of risk vector, also provides significant basis for decision making on risk management.

Keywords: risk assessment, risk management, industry, risk-generating factor, risk matrix.

This work is licensed under a Creative Commons Attribution 4.0 International License http://creativecommons.org/licenses/by/4.0/

Statement of the problem and its connection with important scientific and practical tasks. Successful operation of industrial enterprise today is possible only if it manages its risks effectively. In spite of the fact that for certain types of economic activity (financial, investment) accumulated experience in risk assessment and risk management, have been accumulated in general, the risks inherent in industrial enterprises as complex industrial systems have not been sufficiently studied. Therefore, today it is extremely relevant to develop the comprehensive system of risk management of industrial enterprises as production systems.

The analysis of the latest publications on the problem.The main theoretical aspects of risk assessment and risk management are considered in the fundamental works of A. Smith [1], F.H. Knight [2], J. Shumpeter [3]. Among contemporary foreign economists who are studying the risk problem in entrepreneurship, it is possible to identify E. Holmes [4], K. Arrow [5], A.P. Algin [6], I.T. Balabanov [7], A.G. Badalova [8]. The definition of risk and the characteristics of the methods of managing it were also reflected in the works of Ukrainian economists: I.U. Ivchenko [9], V.V. Vitlinsky [10], V.M. Granaturov [11], V.V. Lukyanova [12] and others.

It should be noted, however, that most studies implement individually short-term or long-term risk predictions. Identification, forecasting and management processes for these risks differ from each other, with little attention being paid to modern risk management.

Consequently, for today, the development and implementation of a methodology for risk assessment and risk management of industrial enterprises as production systems in the short and long period, with further coordination of the results, is extremely important.

Forming of the aims of the research. The aim of the work is to summarize the approaches to the risk assessment and risk management of industrial enterprises, justifying the need for a comprehensive study of the risks of industrial enterprises as production systems which involves a separate assessment of short-term and longterm risks with further harmonization of the obtained results.

Giving an account of the main results and their substantiation. In current risk management, the risks of production system are understood as an event or action, a group of events or actions that relate to the operation and development of production system and the occurrence of which involves deviations in the implementation of the developed strategy and financial results of performance of the production system from the predicted, expected or scheduled. Negative deviations in the implementation of the developed strategy can be understood as obtaining negative financial results in the long-term period. Consequently, implementation of the above- 
mentioned risks leads to negative financial results in the short-and long-term periods.

The assessment of the short-term and long-term risks of industrial enterprises has significant differences between them, which is neglected in the theory and practice of modern risk management [13].

Most studies implement exclusively short-term risk assessment or long-term one. Such approach leads to violation of the principle of continuity of the management process and can lead to significant negative consequences.

The main differences in the short-term and longterm risk assessment processes are shown below (figure $1)$.

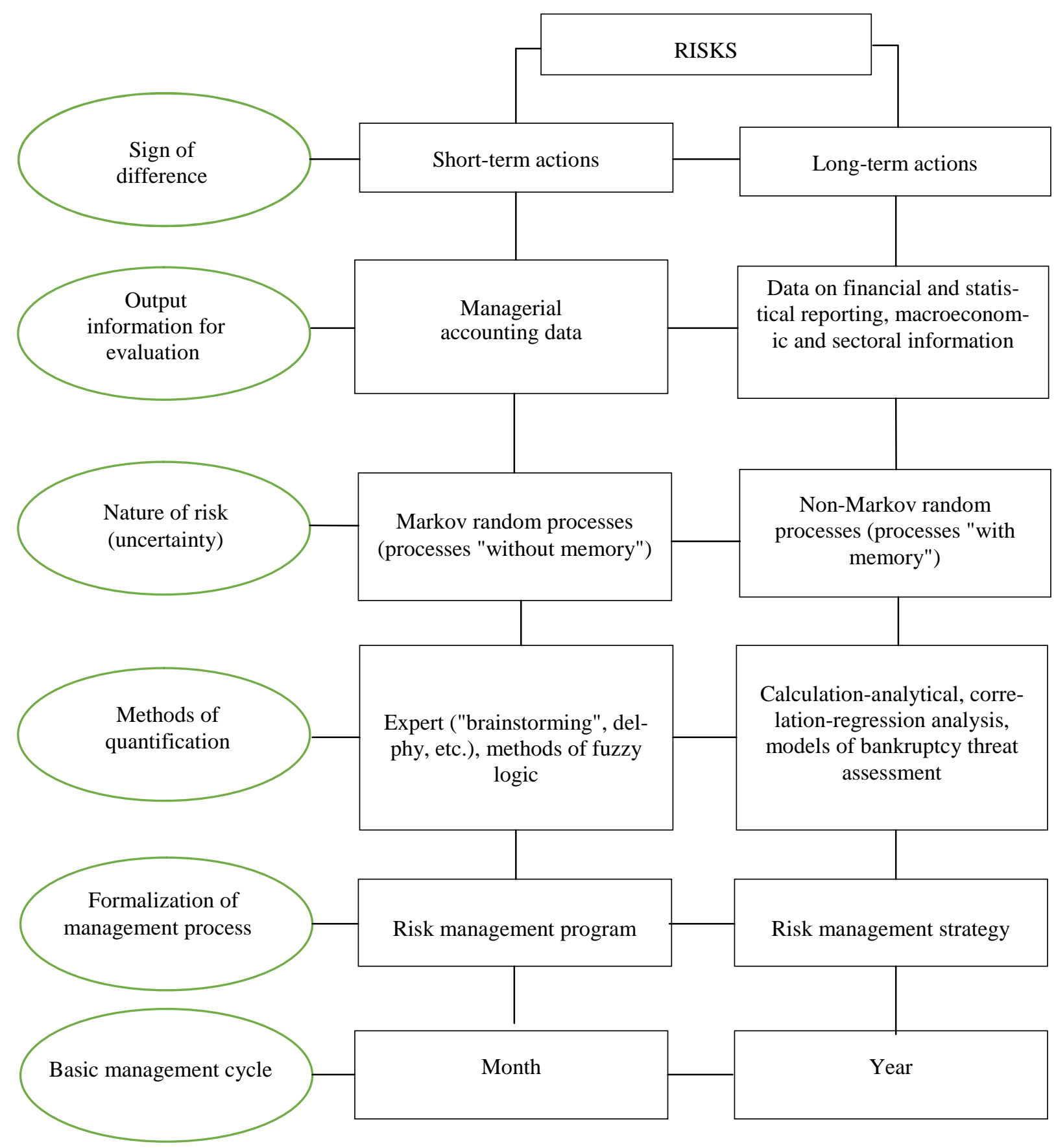

Fig. 1 - Features of assessment and management of short and long-term risks* * compiled by the author

Regardless of the duration of forecast period, direct assessment of economic risk includes such steps as identification of risks, qualitative and quantitative risk assessment. In addition to the differences in identification and qualitative risk assessment, as mentioned above, it is important that in quantifying short-term and long-term risks, most methods that are successfully used to assess the first risks are ineffective or generally incapable in assessment of others, and vice versa. 
Let us now stop on the peculiarities of assessment the short-term risks of industrial enterprises. The procedure for identifying these risks is labor-intensive and depends mainly on the qualification of a risk manager or a group of professionals who are subjects of risk management. The most appropriate of the requirements for professionalism of risk management agent and assessment of impact on the main indicator of short-term risk of industrial enterprises (operating profit) is the identification of risks based on their grouping in accordance with the stages of the operational process (supply, production, sales) [14].
Further, it is necessary to detail the possible impact of risks on the relevant stages of the operating process in the form of description of the possible event (effect of risk-generating factor).

The obtained primary information should reflect not only the full list of possible events in the implementation of relevant risks but also contain the information as to which factors of the income formation these events are displayed.

The information on the adverse impact of riskgenerating factors on the profit indicator from operating activities can be presented in the form of the following table (risk matrix).

Table 1

Matrix of short-term risks of industrial enterprises *

\begin{tabular}{|c|c|c|c|c|c|c|c|c|c|c|c|c|c|}
\hline \multirow{2}{*}{\multicolumn{2}{|c|}{$\begin{array}{c}\begin{array}{c}\text { Stages of operational } \\
\text { process }\end{array} \\
\text { Factors of risk } \\
\end{array}$}} & \multicolumn{3}{|c|}{ Supply } & \multicolumn{3}{|c|}{ Production } & \multicolumn{3}{|c|}{ Distribution } & \multicolumn{3}{|c|}{$\begin{array}{l}\text { Other opera- } \\
\text { tional processes }\end{array}$} \\
\hline & & 1 & 2 & $\ldots$ & $\ldots$ & $\ldots$ & $\ldots$ & $\ldots$ & $\ldots$ & $\ldots$ & $\ldots$ & $\ldots$ & $\mathrm{n}$ \\
\hline \multicolumn{14}{|c|}{$\begin{array}{l}\text { Possible events } \\
\end{array}$} \\
\hline \multicolumn{14}{|c|}{ Object of influence } \\
\hline 1 & Price for products & $*$ & & & & & & & & $*$ & & & \\
\hline 2 & Sales volume & & & $*$ & & & & $*$ & & & & & * \\
\hline 3 & Cost & & $*$ & & $*$ & $*$ & $*$ & & $*$ & & $*$ & $*$ & \\
\hline & including structural elements & & $*$ & & * & * & $*$ & & $*$ & & $*$ & $*$ & \\
\hline
\end{tabular}

*Compiled by the author

When filling the matrix cells, special attention should be paid to the fact that many risk-generating factors make an indirect (mediated) effect on profit-making indicators (factors of the $2 \mathrm{nd}, 3 \mathrm{rd}$, etc. levels). This fact can be displayed in the matrix with arrows that show the essence of influence of risk-generating factors on indicators that generate profits. For this purpose it is expedient to introduce such category as the quality of products, into matrix since many risk-generating factors have direct impact on the quality of products and only indirectly on the indicators that generate profits. Quality in this case is transit factor for the formation of profits, since it is not directly used in its calculation but is a factor in changing the demand for products and prices for them.

The direct effect of risk-generating factors is represented in the matrix by symbols X (ij) -k (effect of event " $\mathrm{K}$ " of risk-generating factor " $\mathrm{j}$ " on profit-making indicator "i"), indirect - $\mathrm{Y}$ (i.j) -k; y2 (i.j) -k is indirect influence of risk-generating factor of level 2, $\mathrm{Yn}$ (i.j) $-\mathrm{k}$ is the indirect influence of risk-generating factor of $n$-th level).

In order to identify the most significant risk factors for the company, as well as profit-making indicators the most vulnerable to the risk it is necessary to quantify the impact of each factor on the resulting indicators. In other words, it is necessary to quantify the value of each variable $X(i, j)-k$ and $Y_{n}(i, j)-k$. It is expedient to carry out such a procedure on the following criteria:

- for variables X (ij) -k

1 - probability of implementing a riskgenerating factor $\mathrm{j}$;
2 - probability of occurrence of the event $\mathrm{K}$ after the implementation of the risk-generating factor $\mathrm{j}$;

3 - magnitude of damage (negative impact on the resulting index i) as a result of the occurrence of the event $\mathrm{K}$.

Probability of occurrence of an event after the implementation of the risk-generating factor $\mathrm{j}$ can be determined by the formula of full probability:

$$
\mathrm{P} \kappa=\mathrm{Ph} * \mathrm{Phh}_{\kappa} \text {, }
$$

where $\mathrm{Ph}$ - probability of implementing a riskgenerating factor;

Phh ${ }_{K}$ - probability of occurrence of an event in the condition of the implementation of risk-generating factor $\mathrm{j}$.

The value of variable $X(\mathrm{ij})-\mathrm{k}$ is determined by the formula:

$$
\mathrm{X}(\mathrm{ij})-\kappa=\mathrm{P} \kappa^{*} \mathrm{H},
$$

where $\mathrm{H}$ - magnitude of the loss in relative terms (negative impact on the resulting index i) as a result of the occurrence of the event $\mathrm{K}$.

- for variables $\mathrm{Y}(\mathrm{i}, \mathrm{j})-\mathrm{K}$ : factor $\mathrm{j}$;

1 - probability of implementing risk-generating

2 - probability of occurrence of the event $\mathrm{K}$ after the implementation of risk-generating factor $\mathrm{j}$;

3 - probability of indirect negative influence of risk factor $\mathrm{j}$ after occurrence of the event $\mathrm{K}$;

4 - magnitude of the indirect damage (negative impact on the resulting index i) as a result of the occurrence of the event $K$. 

formula:

Variable value У(ij)-к thus is determined by the

$$
\text { У(ij)-к }=\text { РК*Py*H, }
$$

where Py - probability of indirect negative influence of risk-generating factor $\mathrm{j}$ after occurrence of an event K;

It is obvious that calculation of the indirect effect of the $n$-th level of the risk-generating factor $j$ is carried out in the following way:

$$
\text { Уn(ij)-к }=\mathrm{P}^{*} \text { Pyy }_{1} * . . \text { Pyy }_{n} * \mathrm{H},
$$

where Pyy ${ }_{n}$ - probability of indirect negative influence of $n$-th level of risk-generating factor $j$ after occurrence of an event $\mathrm{K}$.

After determining all values in all filled cells of matrix, that is, calculating the quantitative value of riskgenerating factors for each possible occurrence (possible event) of formulas 3-5, it is expedient to assess the level of risk at individual stages of the operating process and by individual indicators (factors) of profit generation from operating activities. The calculation of the level of risk for each of its types is carried out by calculating the sum of cell matrices of the matrix on the corresponding lines (risks of the stages of the operating process) and columns (risks of factors of the formation of profits from operating activities).

Such assessment is necessary to determine the force of influence of each group of risks on activity of the enterprise, as well as is the primary source of information for making appropriate decisions on risk management in the context of the received groups.

The final stage of quantitative risk assessment of an enterprise as a production system with the help of the proposed matrix is calculation of the integral risk indicator as a total overall risk assessment at all stages of the operating process or indicators of the formation of the operating activity income.

In our opinion, it is advisable to assess the impact of long-term risks on long-term industrial enterprises by focusing on the possibilities of these enterprises to ensure their sustainable development in conditions of uncertainty and aggressiveness of the market environment. This approach allows us to determine the ability of an enterprise to operate effectively under risk as latent, i.e. hidden, feature of enterprise. Consequently, analysis of the level of a long-term risk is to assess the level of the indicated latent symptom which can be implemented with the help of methods of multivariate statistical analysis, namely instruments of the taxonomic analysis, methods of cluster and discriminant analysis with further advanced research using means of factor analysis of factors of the second order, which can also be considered as latent signs of enterprise (indicators of business activity, efficiency of use of available resources, liquidity and creditworthness, property status, etc.) [15]. At the same time, in our opinion, as the main indicators of the level of long-term risk, it is appropriate to use absolute and relative indicators of profitability of activities, as well as statistical characteristics that describe the dynamics of these indicators.

Distribution of risk-generating factors into the short-term and long-term ones requires a procedure for coordinating the results of each type of risk assessment. To obtain a general assessment of the level of riskiness of an industrial enterprise, it is necessary to obtain the results of short-term and long-term risk forecasting in a comparable form, which can be achieved through the use of various standardization, rationing and scaling techniques. After obtaining the converted estimates of shortterm and long-term economic risks it is necessary to assess the overall level of riskiness of an enterprise.

The express-assessment of the level of general risk can be carried out as follows:

Ygen $=\alpha *$ Yshort. $+(1-\alpha) *$ Ylong.,

where Yshort. - a short-term risk level;

Ylong. - a long-term risk level;

$\alpha-$ a coefficient of coherence of a short-term and a long-term risk.

The coefficient of coherence of a short-term and a long-term risk characterizes the ratio of risks in terms of their impact on the activities of an enterprise and is in range from 0 to 1 . The value of this coefficient depends on the dynamics of levels of short-term and long-term risk in previous periods of time, the stage of the company's life cycle, enterprise development strategies etc. If the quantitative measurement of this coefficient using economic and mathematical methods is impossible, it is expedient to use expert methods. In this case coefficient $\alpha$ will express the subjective perception of a person who is interested in risk management, about impact of short and long-term risks on the company's activities.

In order to characterize the level of risk in terms that can be understood by general management of a company its next gradation may be proposed (see table 2).

Table 2

Gradation of levels of riskiness of a enterprise*

\begin{tabular}{|c|c|c|c|c|c|c|}
\hline Value Ygen. & Less than 0,2 & $\begin{array}{c}\text { from } 0,2 \text { to } \\
0,4\end{array}$ & $\begin{array}{c}\text { from } 0,4 \\
\text { to } 0,6\end{array}$ & $\begin{array}{c}\text { from } 0,6 \text { to } \\
0,75\end{array}$ & $\begin{array}{c}\text { from } 0,75 \text { to } \\
0,9\end{array}$ & More than 0,9 \\
\hline $\begin{array}{c}\text { Linguistic risk } \\
\text { assessment }\end{array}$ & minimal risk & $\begin{array}{c}\text { acceptable } \\
\text { risk }\end{array}$ & high risk & $\begin{array}{c}\text { threatening } \\
\text { risk }\end{array}$ & critical risk & catastrophic risk \\
\hline
\end{tabular}

* Compiled by the author

The uneven distribution of risk-level ranges (from the menacing one) is a consequence of the uneven impact of the overall risk on an enterprise activity and the possible emergence of the multiplier effect. Each level of risk should be consistent with its own program and re- sponse strategy with corresponding material (monetary) and time limits: the more risky the risk level is, the more significant should be the material limits and the high speed of taking anti-crisis decisions (measures to minimize the risk). 
Express risk assessment, as well as any other express assessment, has its advantages (relative speed and simplicity of calculations, obtaining an unambiguous assessment of the level of risk) and disadvantages (does not allow conducting a thorough analysis of the risk of activity, averages assessments and may lead to false conclusions). The need for more advanced study of the effect of risks on the activities of enterprises requires construction of a more detailed assessment system than the pro- posed one during the express analysis. Each relationship or a group of ratios of long-term and short-term risks must correspond to a certain program of enterprise behavior and assessment of quality of risk management process with a definition of directions for its improvement.

It is expedient to allocate risk areas according to the ratio of the level of short-term and long-term risks in a matrix form (table 3).

Table 3

Risk matrix of an enterprise*

\begin{tabular}{|c|c|c|c|c|c|c|}
\hline Level of & 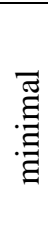 & 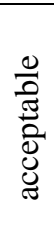 & $\frac{\sqrt{000}}{\Xi}$ & 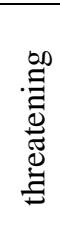 & : & 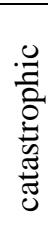 \\
\hline minimal & & & & & & \\
\hline acceptable & & & & & & \\
\hline high & & & & & & \\
\hline threatening & & & & & & \\
\hline critical & & & & & & \\
\hline catastrophic & & & & & & \\
\hline
\end{tabular}

* Compiled by the author

The quantitative assessment of short- and longterm risks of the enterprise will correspond to one of the quadrants of the matrix, the field of which can be divided into risk areas.

Zones of balanced risk are on the main diagonal of the matrix: on the left - the area of acceptable risk, on the right - the area of inappropriate risk. In the side diagonal there are areas of unbalanced risk: on the left - the area of "short-sighted" risk management (level of longterm risk significantly exceeds level of short-term), on the right - zone of "far-sighted" risk management (level of short-term risk significantly exceeds level of long-term)

Each allocated zone should require a set of actions to increase the efficiency of the process of risk management at the enterprise. Thus, for the zone of unacceptable risk, the development and implementation of immediate measures to minimize short-term risk with significant adjustments to the strategy of managing longterm risks is of a paramount importance. For the zone of unbalanced risk ("far-sighted" risk management), a qualitative change in the short-term risk management program can be proposed in support of the strategy for managing long-term risks. For a zone of unbalanced risk ("short-sighted" risk management), it is logical to support a short-term risk management program and change the strategy for managing long-term risks. Support for the current program and risk management strategy is relevant to the area of acceptable risk.

The analysis of the dynamics of the level of risk activity is important for assessment the effectiveness of risk management. Comparison of changes in the levels of riskiness of activity allows to distinguish four possible risk vectors.

When reducing the levels of both short-term and long-term risk, we can talk about the overall increase in efficiency of enterprise and its risk management. Accordingly, presence of reverse trends (growth of both shortterm and long-term risk) indicates a decrease in the efficiency of the enterprise and its risk management and accumulation of overall risk. Reduction of short-term risk and increase long-term tells about errors in developing of risk management strategy. It is also likely that there will be increase in the exposure to enterprise activity of systematic risks. Growth of short-term risks and reduction in long-term risks means existence of errors in the development of a risk management program. In this case, the potential increase in reserves for improving the effectiveness of risk management in general may be due to more weighty and inert long-term factors.

Conclusions and prospects of the further investigations. 1 - Need for effective risk management requires building a comprehensive system of qualitative and quantitative risk assessment. This, in its turn, is possible on the basis of separate study of risks in the short and long term which is the result of significant differences in their essence, sources of information for analysis, assessment methods, cycles of management processes, etc. The final stage of quantification of risks is harmonization of the results of the analysis of short-term and long-term risks.

2 - Assessment of risks of industrial enterprises as production systems in the short-term period consists of calculating possible influence of risk-generating factors on the indicators of operating profit formation. For such quantitative assessment, it is proposed to use matrix of short-term risks, the main advantage of which is clarity and simplicity in terms of possibility of its practical application. In our opinion, it is advisable to assess the long-term risks of enterprises as determining the level of the latent character of the enterprise which is the ability 
of the enterprise to ensure its sustainable development in conditions of uncertainty and aggressiveness of the market environment. Such assessment should be based on the analysis of the competitive environment by key indicators that characterize relevant manifestations of the indicated feature.

3 - Harmonization of the results of short-term and long-term risk assessment, as well as the effectiveness of management risk, is possible in the form of ex- press assessment and in more detail with the risk matrix and risk vector analysis.

4 - Further development of the methodological approaches suggested in the work is seen in the introduction of tactical risk management in the risk management of enterprises as a connecting element between the management of the short-term (operational level) and longterm risks (strategic level) that can be implemented with the availability of significant financial, time and personnel resources.

\title{
References
}

1. Smit, A. (2016). Ssledovanie o prirode i prichinah bogatstva narodov (1-3). M.: Eksmo.

2. Nayt, F. H. (2003). Risk, neopredelennost i pribyil. M.: Delo.

3. Shumpeter, Y. (1982). Teoriya ekonomicheskogo razvitiya (issledovanie predprinimatelskoy pribyili, kapitala, kredita, protsenta i tsikla kon'yunkturyi). M.: Progress.

4. Holms, E. (2007). Risk-menedzhment. M.: Eksmo.

5. Errou, K. D. (2003). Vospriyatie riska v psihologii i ekonomicheskoy nauke. Retrieved from http://ecsocman.hse.ru/text/18728983/

6. Algin, A. P. (1994). Grani ekonomicheskogo riska. M.: Znanie.

7. Balabanov, I. T. (1996). Risk-menedzhment. M.: Finansyi i statistika.

8. Badalova, A. G. (2006). Upravlenie riskami proizvodstvennyih sistem: Teoriya, metodologiya, mehanizmyi realizatsii. M.: «Stankin», «YaNUS-K».

9. Ivchenko, I. Yu. (2004). Ekonomichni ryzyky. K.: Tsentr navchalnoi literatury.

10. Vitlinskyi, V. V., Nakonechnyi, S. I., \& Sharapov, O. D. (1996). Ekonomichnyi ryzyk i metody yoho vymiriuvannia. K.: IZMN.

11. Granaturov, V. M. (2002). Ekonomicheskiy risk: Suschnost, metodyi izmereniya, puti snizheniya. M.: Delo i servis.

12. Luk'ianova, V. V., \& Holovach, T. V. (2007). Ekonomichnyi ryzyk. K.: Akademvydav.

13. Shalenyi, V. A. (2017). Osnovni metodychni zasady korotkostrokovoi ta dovhostrokovoi otsinky ryzykiv promyslovykh pidpryiemstv. Prychornomorski Ekonomichni Studii, (22), 133-137.

14. Basiurkina, N. Y. (2017). Pryvablyvist kharchovoho biznesu v Ukraini (N. Y. Basiurkina, Ed.). Odesa: Odeska nats. akad. kharchovykh tekhnolohii.

15. Yankovyi, O. H. (2015). Latentni oznaky v ekonomitsi. Odesa: Atlant.

Received 2 February 2018

Approved 16 February 2018

Available in Internet 31.03.2018

\author{
Басюркина Н.И. \\ доктор экономических наук, доцент \\ E-mail:nbas@email.ua \\ Шаленый В.А. \\ старший преподаватель \\ кафедра управления бизнесом \\ Одесская национальная академия пищевых технологий \\ Ул. Канатная, 112, г.Одесса, Украина, 65039 \\ E-mail: shalenyy@i.ua

\section{ОСОБЕННОСТИ ОЦЕНКИ РИСКОВ ДЕЯТЕЛЬНОСТИ ПРОМЫШЛЕННЫХ ПРЕДПРИЯТИЙ}

В статье рассмотрены основные теоретические аспекты оценки рисков промышленных предприятий в краткосрочном и долгосрочном периодах. Определено, что построение эффективной системы управления рисками требует раздельного исследования рисков в краткосрочном и долгосрочном периодах, что является следствием значительных различий в их сущности, информационного обеспечения и методов оценки, цикличности управленческих процессов. В работе выделены ключевые признаки краткосрочных и долгосрочных рисков, свойственные промышленным предприятиям. 
Оценка рисков промышленных предприятий в краткосрочном периоде заключается прежде всего в расчете возможного влияния рискообразующих фракторов на показатели фрормирования операционной прибыли. Для такой количественной оценки предложено использовать матрицу краткосрочных рисков, основным преимуществом которой является ее простота с точки зрения возможности практического применения. Оценку долгосрочных рисков предприятий предлагается проводить как определение уровня латентного признака предприятия, суть которого заключается в способности предприятия обеспечить свое устойчивое развитие в условиях неопределенности и агрессивности рыночной среды.

Комплексность оценки уровня риска деятельности промышленных предприятий заключается в согласовании результатов анализа краткосрочного и долгосрочного рисков. Указанная методика в зависимости от целей проведения оценки, имеющихся ресурсов и других ограничений может быть реализована в виде экспресс-оценки (упрощенная оценка рисков) и в виде матрицы рисков (углубленная оценка рисков). Целесообразность использования экспресс-оценки заключается, прежде всего, в анализе динамики уровня риска на предприятии. С помощью позиционирования оценки уровня риска предприятия в определенной области матрицы рисков (углубленная оценка рисков) возможно определение основных резервов снижения общего уровня риска и повышение эффективности рискменеджмента. Оценка динамики уровня риска деятельности, полученная в виде вектора риска, также может являться базой для принятия решений по управлению рисками.

Ключевые слова: оценка рисков, управление рисками, промышленность, рискообразующий фрактор, матрица рисков.

\author{
Басюркіна Н.Й. \\ доктор економічних наук, доцент \\ E-mail: nbas@email.ua \\ Шалений В.А. \\ старший викладач \\ кафедра управління бізнесом \\ Одеська національна академія харчових технологій \\ вул. Канатна, 112, Одеса, Україна, 65039 \\ E-mail: shalenyy@i.ua
}

\title{
ОСОБЛИВОСТІ ОЦІНКИ РИЗИКІВ ДІЯЛЬНОСТІ ПРОМИСЛОВИХ ПІДПРИЕМСТВ
}

У статті розглянуто основні теоретичні аспекти оцінки ризиків промислових підприємств в короткостроковому та довгостроковому періодах. Визначено, що побудова ефективної системи управління ризиками вимагає роздільного дослідження ризиків в короткостроковому та довгостроковому періодах, що $€$ наслідком значних відмінностей у їх сутності, інформаційного забезпечення та методів оцінки, циклічності управлінських процесів тощо. В роботі виділені основні ознаки короткострокових та довгострокових ризиків, властиві промисловим підприємствам.

Оцінка ризиків промислових підприємств в короткостроковому періоді полягає, насамперед, у розрахунку можливого впливу ризикоутворюючих чинників на показники формування операційного прибутку. Для такої кількісної оцінки запропоновано використовувати матрицю короткострокових ризиків, основною перевагою якої є зрозумілість та простота з точки зору можливості її практичного застосування. Оцінку довгострокових ризиків підприємств пропонується проводити як визначення рівня латентної ознаки підприємства, яка полягає у здатності підприємства забезпечити свій сталий розвиток в умовах невизначеності та агресивності ринкового середовища

Комплексність оцінки рівня ризикованості діяльності полягає в узгодженні результатів аналізу короткострокового та довгострокового ризиків. Зазначена методика в залежності від цілей проведення оцінки, наявних ресурсів та інших обмежень може бути реалізована у вигляді експрес-оцінки (спрощена оцінка ризиків) та у вигляді матриці ризиків (поглиблена оцінка ризиків). Доцільність використання експрес-оцінки полягає, насамперед, в аналізі динаміки рівня ризику на підприємстві. За допомогою позиціонування стану ризикованості діяльності підприємства в певній області матриці ризиків можливим $€$ визначення основних резервів зниження загального рівня ризику та підвищення ефективності ризик-менеджменту. Оцінка динаміки рівня ризику діяльності, отримана у вигляді вектору ризику, також дає значне підґрунтя для прийняття рішень по управлінню ризиками.

Ключові слова: оцінка ризиків, управління ризиками, промисловість, ризикоутворюючиий чинник, матриця ризиків. 


\section{Література}

1. Смит А. Исследование о природе и причинах богатства народов (книги 1-3) / А. Смит. - М.: Эксмо, 2016. - $1056 \mathrm{c}$.

2. Найт Ф.Х. Риск, неопределенность и прибыль / Ф.Х. Найт. М.: Дело, 2003. - 360 с.

3. Шумпетер Й. Теория экономического развития (исследование предпринимательской прибыли, капитала, кредита, процента и цикла конъюнктуры) / Й. Шумпетер. - М.: Прогресс, 1982. - 456 с.

4. Холмс Э. Риск-менеджмент / Э Холмс. - М.: Эксмо, 2007 - 312 с.

5. Эрроу К.Д. Восприятие риска в психологии и экономической науке [Электронный ресурс] / К.Д. Эрроу. - Режим доступа: http://ecsocman.hse.ru/text/18728983/

6. Альгин А.П. Грани экономического риска / А.П. Альгин. - М.: Знание, 1994. - 264 с.

7. Балабанов И.Т. Риск-менеджмент / И.Т. Балабанов. - М.: Финансы и статистика, 1996. - 192 с.

8. Бадалова А.Г. Управление рисками производственных систем: теория, методология, механизмы реализации : монография / А.Г. Бадалова. - М : «Станкин», «ЯНУС-К», 2006. -328 с.

9. Івченко І.Ю. Економічні ризики / І.Ю. Івченко. - К. : Центр навчальноі літератури, 2004. - 304 с.

10. Вітлінський В.В. Економічний ризик і методи його вимірювання / Вітлінський В.В., Наконечний С.І., Шарапов О.Д. - К.: ІЗМН, 1996. - 400 с.

11. Гранатуров В.М. Экономический риск: сущность, методы измерения, пути снижения / В.М. Гранатуров. - М.: Дело и сервис, 2002. - 160 с.

12. Лук'янова В.В. Економічний ризик / В.В. Лук'янова, Т.В. Головач. - К.: Академвидав, 2007. - 464 с.

13. Шалений В.А. Основні методичні засади короткострокової та довгострокової оцінки ризиків промислових підприємств / В.А. Шалений // Причорноморські економічні студії. - 2017. - №22. - С. 133 - 137.

14. Привабливість харчового бізнесу в Україні: [монографія] / [Н.Й. Басюркіна та ін.]; за ред. д.е.н. Н.Й, Басюркіної; Одеська нац. акад. харчових технологій. - Одеса: ОНАХТ, 2017. -192 с.

15. Янковий О.Г. Латентні ознаки в економіці: [монографія] / О.Г. Янковий. - О. : Атлант, 2015. - 168 с.

Стаття надійшла 2.02.2018 Стаття прийнята до друку 16.02.2018 Доступно в мережі Internet 31.03.2018 